\title{
Article \\ Groundwater Quality of Drinking Water Wells in the West Bank, Palestine
}

\author{
Nidal Mahmoud ${ }^{1, *}$, Omar Zayed ${ }^{2}$ and Branislav Petrusevski ${ }^{3}$ \\ 1 Institute of Environmental and Water Studies (IEWS), Birzeit University, West Bank, Birzeit P627, Palestine \\ 2 Palestinian Water Authority, West Bank, Ramallah P606, Palestine; ozayed2001@yahoo.com \\ 3 IHE-Delft Institute for Water Education, Westvest 7, 2601 DA Delft, The Netherlands; \\ b.petrusevski@un-ihe.org \\ * Correspondence: nmahmoud@birzeit.edu; Tel./Fax: +970-2-2982-120
}

check for

updates

Citation: Mahmoud, N.; Zayed, O.; Petrusevski, B. Groundwater Quality of Drinking Water Wells in the West Bank, Palestine. Water 2022, 14, 377. https://doi.org/10.3390/w14030377

Academic Editors: Yung-Tse Hung, Hamidi Abdul Aziz, Issam

A. Al-Khatib, Rehab O

Abdel Rahman and Tsuyoshi Imai

Received: 16 December 2021

Accepted: 20 January 2022

Published: 26 January 2022

Publisher's Note: MDPI stays neutral with regard to jurisdictional claims in published maps and institutional affiliations.

Copyright: (C) 2022 by the authors. Licensee MDPI, Basel, Switzerland. This article is an open access article distributed under the terms and conditions of the Creative Commons Attribution (CC BY) license (https:// creativecommons.org/licenses/by/ $4.0 /)$.

\begin{abstract}
Groundwater, the main drinking water source in the West Bank, is highly vulnerable to pollution given the karstic nature of the aquifer. This study was aimed at screening the quality of groundwater used for water supply, in terms of physicochemical and microbiological properties, and heavy metals concentrations. Attention was given to groundwater chemistry, using piper and Durov diagrams, to assess potent impact of pollution on groundwater. Twenty-nine groundwater samples from selected wells, representing the different groundwater fields in the West Bank, were collected and analyzed. The results revealed that the concentration of the ions and parameters affecting the aesthetic and health related water quality, such as $\mathrm{Cl}^{-}, \mathrm{Na}^{+}, \mathrm{NH}_{4}{ }^{+}, \mathrm{TDS}$, and $\mathrm{NO}_{3}{ }^{-}$, and selected (semi) metals, including $\mathrm{Cr}, \mathrm{Cu}, \mathrm{Fe}, \mathrm{Mn}, \mathrm{Pb}, \mathrm{Cd}$, and $\mathrm{As}$, are within the limits recommended for drinking water. The dominant cations and anions were in the order of $\mathrm{Ca}^{2+}>\mathrm{Na}^{+}>\mathrm{Mg}^{2+}>\mathrm{K}^{+}>\mathrm{NH}_{4}^{+}$and $\mathrm{HCO}_{3}{ }^{-}>\mathrm{Cl}^{-}>\mathrm{NO}_{3}{ }^{-}>\mathrm{SO}_{4}{ }^{2-}$, respectively. The total average groundwater hardness is approximately $2.1 \mathrm{mmol} / \mathrm{L}$ and can be attributed to calcium (approximately $60 \%$ ) and magnesium. The major ground water types in the West Bank were fresh water $\left(\mathrm{Ca}-\mathrm{Mg}-\mathrm{HCO}_{3}\right)$, fresh water mixed with another water type (Ca-Mg-Na- $\mathrm{HCO}_{3}$ or $\left.\mathrm{Ca}-\mathrm{Mg}-\mathrm{HCO} 3-\mathrm{Cl}\right)$, and extreme water type (Na-Ca-Mg$\mathrm{HCO}_{3}-\mathrm{Cl}$ or $\mathrm{Na}-\mathrm{Ca}-\mathrm{HCO}_{3}-\mathrm{Cl}$ ) showing high TDS, $\mathrm{Cl}^{-}$and $\mathrm{Na}^{+}$. Signs of pollution, namely elevated levels of nitrate and ammonium, were, however, observed even in some deep wells (>600 m), despite the thick cover of soil, tapping the Lower Ceneomanian confined aquifer.
\end{abstract}

Keywords: groundwater quality; karst; pollution; wastewater; drinking water; West Bank

\section{Introduction}

High-quality fresh drinking water resources are essential for quality of life, notably in water-scarce areas. Due to the rapid increase in the world's population, along with noticeable economic growth, freshwater resources have been stretched to the limit in many countries and regions of the world [1].

Groundwater is an essential source for drinking water production; however, its quality might be very different in different parts of the world and could also vary over time. Groundwater is vulnerable to contamination, and it is very difficult to restore its original quality after pollution takes place [2,3]. Several natural and human factors could influence groundwater quality, such as geology, climate, topography, abstraction volumes and vicinity to sea, wastewater discharges, agricultural activities, etc. [1,4,5]. Groundwater contamination with heavy metals, together with geogenic presence of some toxic metals (e.g., arsenic, fluoride, etc.), is of increasing concerns due to their severe ecological and public health impacts. The main sources of heavy metal pollution are agricultural runoffs, uncontrolled discharges of waste(water) from industry, including metal electroplating, mining, etc. Traffic is also an important source of heavy metals pollution [1,6]. This paper deals with a karst system that is typically highly vulnerable to contamination due to the fast transport of pollutants through conduits $[7,8]$. 
Several countries in the Middle East, including Palestine, suffer from water shortage due to predominantly arid to semi-arid climatic conditions. Groundwater is the main source of drinking water in the West Bank and the Gaza Strip that provides fresh water for more than $90 \%$ of all water supplies [9]. Low levels of precipitation results, however, in a limited water recharge of aquifer basins, placing Palestine among countries with the scarcest renewable water resources, constraining economic development and leading to health problems $[9,10]$. Agriculture is the major user of groundwater in Palestine, with reported usage of $45 \%$ of the total groundwater abstracted [11]. The average domestic water consumption is only $72 \mathrm{~L} /$ capita/day in the West Bank, and $96 \mathrm{~L} /$ capita/day in the Gaza Strip $[9,10]$.

The available freshwater resources in the West Bank are seriously threatened by pollution. The main groundwater pollution sources throughout the West Bank are the discharge of untreated wastewater from domestic and industrial sources, agricultural activities, and non-engineered landfill sites $[9,12]$. The yearly generated wastewater in the West Bank is estimated at approximate 50 million cubic meters. Only approximately $30 \%$ of wastewater is collected by sewage systems, while remaining $70 \%$ is discharged in mainly unlined cesspits, resulting in wastewater infiltration into the soil [9]. Furthermore, only $20-30 \%$ of the collected wastewater is treated in wastewater treatment plants, and the rest is discharged untreated in nearby wadis, creating line source pollution.

Groundwater quality needs to be continuously monitored and assessed, given the pollution risks $[13,14]$. A detailed knowledge on groundwater quality can enhance understanding of the hydro-chemical system and promote sustainable development and effective management of groundwater resources [15]. Since the aquifers in the West Bank are karstified, they are particularly vulnerable to pollution [16]. In addition, geology of the region is rather complex. It was recently reported that only four percent of water abstracted in the Gaza Strip fulfils WHO drinking water quality guidelines [17]. In the Gaza Strip of Palestine, fluoride concentrations as high as $2.7 \mathrm{mg} / \mathrm{L}$ were reported [18]. Presence of arsenic in groundwater was recently reported in the north of Jordan [19]. Data on quality of groundwater used for water supply in the West Bank are, however, rather limited and cover relatively small number of wells in the Jordan Valley and North of West Bank. The general perception is that the quality of groundwater used as a drinking water in the West Bank is acceptable, with only a limited number of wells with elevated levels of chlorite and nitrate [17]. No data on possible presence of fluoride, arsenic, and other health hazardous metals in groundwater are available for most of the West Bank.

The aim of the study was to screen the groundwater quality used for water supply in different parts of the West Bank. The specific objectives were to assess the groundwater quality, in terms of physicochemical and microbiological properties (e.g., faecal coliforms), and possible presence of heavy metals. In addition, the geochemical nature of aquifers, and possible contamination from human activities were analyzed using hydro-geochemical tools, including Piper and Gibbs diagrams. We acknowledge the limitation of this study as it was a one-time sampling during the dry season, and only seven wells sampled also during the rainy season.

\section{Study Area}

The study area is the West Bank of Palestine that has a Mediterranean climate which varies from semi-arid in the west to extremely arid in the east and southeast. The annual average rainfall is about $454 \mathrm{~mm}$ and varies from $650 \mathrm{~mm}$ in the western part to less than $100 \mathrm{~mm}$ in the east [10]. There are three main aquifer basins, namely, the Eastern Aquifer (EA), the Western Aquifer (WA), and the North-Eastern Aquifer (NEA) (Figure 1), that are collectively called the mountain aquifer. Based on depth the mountain, aquifer has two main parts: the lower and the upper Cenomanian aquifers, from where the domestic wells are drawing water. The average thickness of these aquifers ranges between 600 and $900 \mathrm{~m}$. The majority of outcropping formations in the West Bank are marine sediments composed of carbonates (such as limestone, dolomite, and chalk) and chert. In 
the West Bank, these rocks extend in age from the Lower Cretaceous to Quaternary with limited exposures of Jurassic rocks. A brief description of the stratigraphic features of the various formations constituting the aquifer system in the three groundwater basins in the West Bank is presented below (Figure 2).

The West Bank is mainly covered by sedimentary carbonate rocks of the Cretaceous period [20]. Lithological composition of the aquifers formations consists mainly of limestone, chalk, marl, and dolomite. Karst features develop over time according to limestone and dolomite rock solubility. In these soluble rocks, fracture and fissure apertures enlarge over time creating a network of conduits with a high hydraulic conductivity. Therefore, any pollution sources in areas with karstified rocks might have severe impacts on groundwater quality, especially in the outcropping zones.

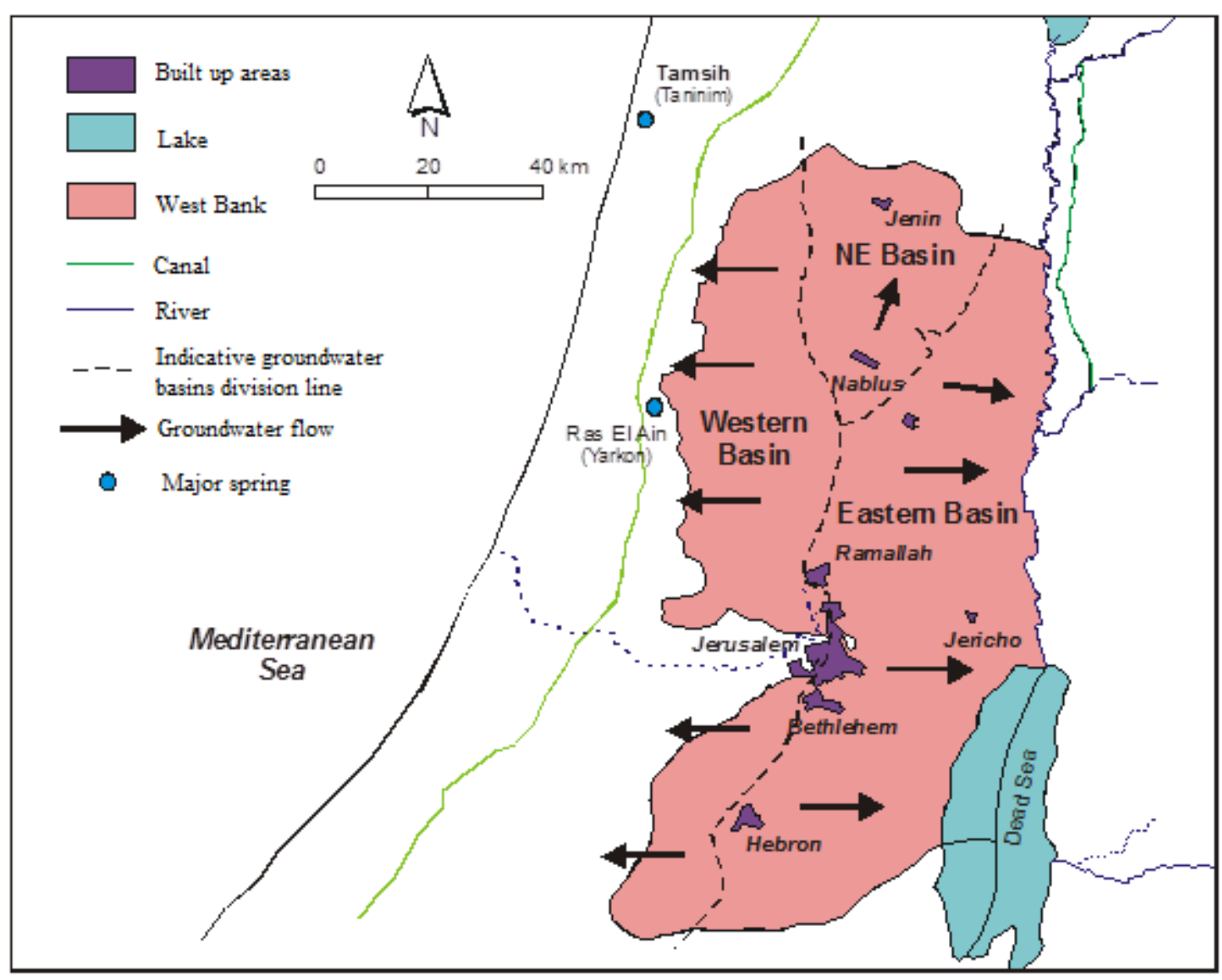

Figure 1. Groundwater basins in the West Bank of Palestine. 


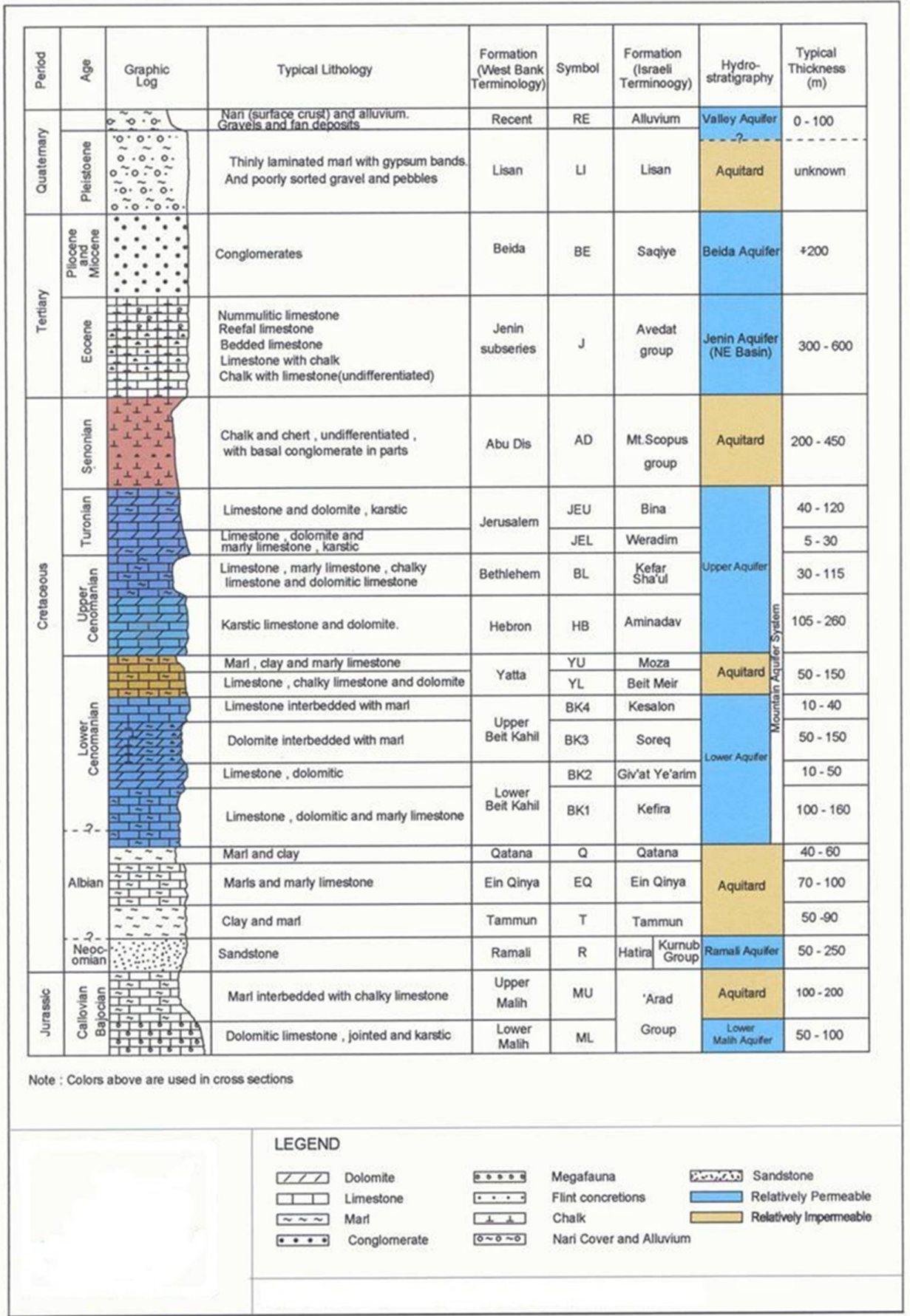

Figure 2. Hydro-stratigraphic section of the West Bank.

\section{Material and Methods}

\subsection{Sampling and Field Work}

Twenty-nine groundwater wells spatially distributed in the West Bank were selected in this study to represent different aquifers (upper and lower) and basins (EA, WA \& NEA) (Figure 3). The wells data (coordinates, locality and governorate, depth, groundwater aquifer and basin, and information on possible pollution sources) were obtained from the Palestinian Water Authority. Groundwater samples from the 29 wells were taken during dry season that typically lasts from March to November. In addition, samples from seven wells were also taken during the rainy season. 


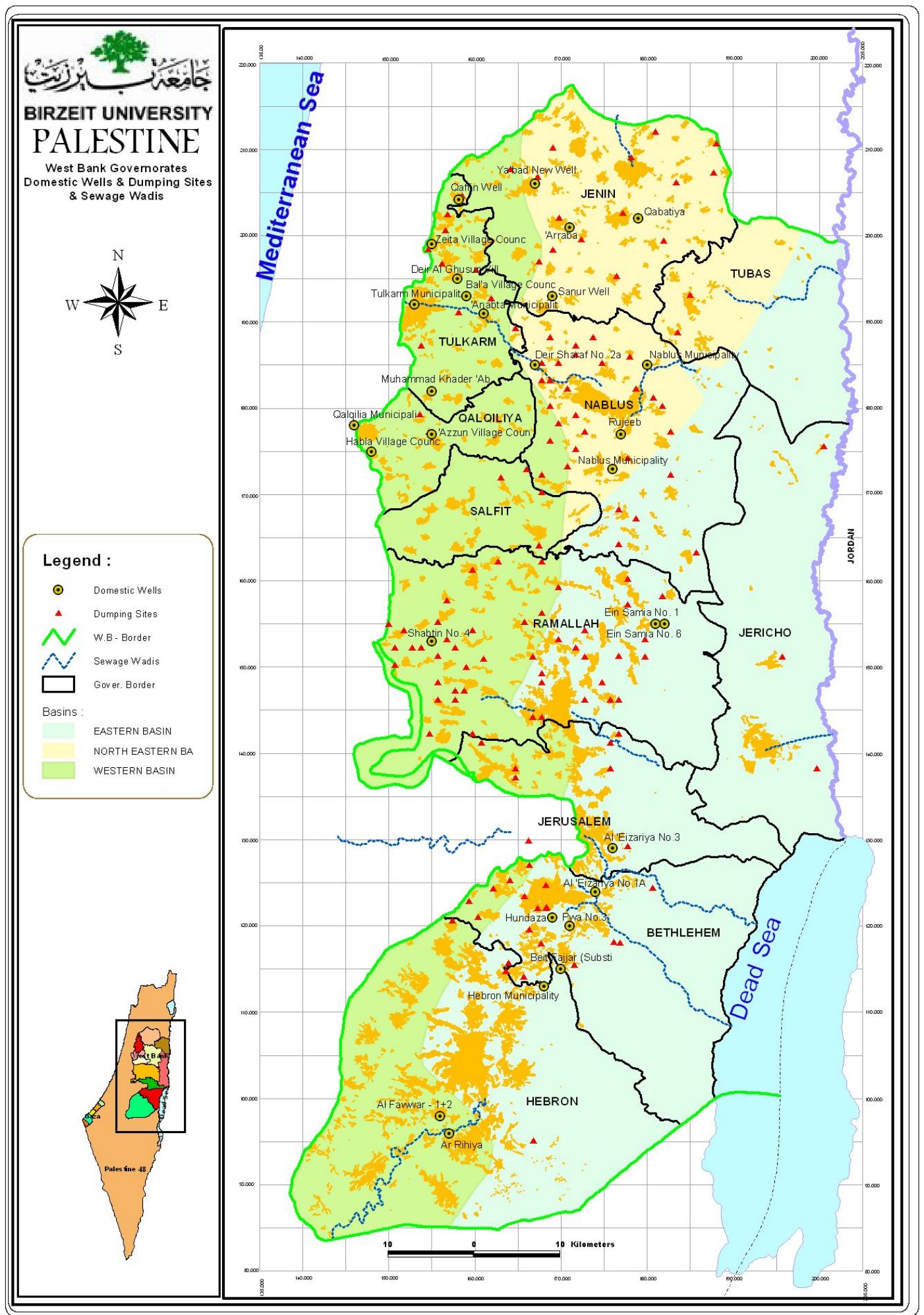

Figure 3. The sampled groundwater wells, wadis polluted with sewage, and non-engineered solid waste dumping sites in the West Bank.

Ground water samples were collected in pyrex sterilized glass bottles $(1000 \mathrm{~mL})$, filtered through a $0.45 \mu \mathrm{m}$ filter (Schleicher and Schuell ME 25, Taufkirchen, Germany), divided into two fractions, and stored at $4{ }^{\circ} \mathrm{C}$. The sample fraction for analyses of cations and trace metals was acidified $(\mathrm{pH}<1.5)$ with analytical grade concentrated nitric acid. $\mathrm{pH}$, temperature, conductivity, and dissolved oxygen (DO) were measured in field, immediately 
after or during sampling, using a portable HACHsensION1 multi meter, with a combined electrode, and a portable $\mathrm{HACH}$ conductivity meter $(\mathrm{HACH}$, Loveland, $\mathrm{CO}, \mathrm{USA})$.

\subsection{Analytical Methods}

Analyses of anions and cations were carried out at the Birzeit University laboratories, and arsenic was analyzed at the IHE-Delft laboratory, The Netherlands. $\mathrm{Cl}^{-}, \mathrm{NO}_{3}{ }^{-}$and $\mathrm{SO}_{4}{ }^{2-}$ were analyzed using a Millipore Waters Capillary Ion Analyzer (CIA). $\mathrm{Na}^{+}, \mathrm{K}^{+}, \mathrm{Ca}^{2+}$, and $\mathrm{Mg}^{2+}$ were analyzed using a Perkin Elmer AAnalyst100 flame atomic absorption spectrometer (manufactured by Perkin Elmer, Waltham, MA, USA). Ammonium concentration was determined according to nesslerization method. Ortho-phosphate $\left(\mathrm{PO}_{4}{ }^{3-}\right)$ concentration was determined according to ascorbic acid method. Trace metals, including fluoride $(\mathrm{F})$, chromium $(\mathrm{Cr})$, cupper $(\mathrm{Cu})$, iron $(\mathrm{Fe})$, manganese $(\mathrm{Mn})$, lead $(\mathrm{Pb})$, and cadmium $(\mathrm{Cd})$, were determined by a Perkin Elmer AAnalyst 600 atomic absorption spectrometer with graphite furnace (manufactured by Perkin Elmer, USA). Fluoride was analyzed using a Thermo Dionex Integrion HPIC system coupled with conductivity detector (manufactured by Thermo Fisher Scientific, Winnipeg, MB, Canada). Thermo Elemental Solaar MQZe-GF 95 with an auto-sampler and a graphite furnace as detector (AAS-GF) was used for arsenic (As) analyses (manufactured by Thermo Fisher Scientific, MB, Canada). The TOC was measured using the Aurora 1030W TOC analyzer (OI Analytical/Xylem, College Station, TX, USA). Fecal coliforms were measured by the membrane filtration technique. All parameters were analyzed according to standard methods [21]. Piper trilinear diagram was used for the classification of groundwater. Furthermore, the evidence of pollution was identified through water quality analysis [22] and pollution sources GIS mapping.

\subsection{Data Presentation and Statistical Analysis}

Data presentation and correlations were carried out using the Aquachem5.1 software. Statistical comparisons of arithmetic means were followed by independent samples t-test" for the measured parameters of the upper and lower aquifers, with $p$ value $<0.05$ considered significantly different.

\section{Results and Discussion}

\subsection{Physicochemical and Microbiological Quality of Groundwater}

Table 1 provides an overview of physical parameters and concentration ranges for major ions in all groundwater samples included in this study, along with the Palestinian standards [23] and WHO guideline values [24]. The following trend was observed for the anion concentrations: $\mathrm{HCO}_{3}{ }^{-}>\mathrm{Cl}^{-}>\mathrm{NO}_{3}{ }^{-}>\mathrm{SO}_{4}{ }^{2-}$, while the cation concentrations were found in the following order: $\mathrm{Ca}^{2+}>\mathrm{Na}^{+}>\mathrm{Mg}^{2+}>\mathrm{K}^{+}$.

Table 1. Physicochemical parameters of the groundwater from 29 wells in the West Bank, Palestine.

\begin{tabular}{|c|c|c|c|c|}
\hline Parameter $^{+}$ & Average (STD) & Range & Palestinian Standards [23] & WHO Guideline [24] \\
\hline $\mathrm{pH}$ & $7.2(0.2)$ & $6.8-7.9$ & $6.5-8.5$ & NA \\
\hline $\operatorname{TDS}(\mathrm{mg} / \mathrm{L})$ & $340.0(56)$ & $265-449$ & 1000 & NA \\
\hline $\mathrm{F}^{-}(\mathrm{mg} / \mathrm{L})$ & $0.3(0.2)$ & $0.1-1.2$ & 1.5 & 1.5 \\
\hline $\mathrm{Cl}^{-}(\mathrm{mg} / \mathrm{L})$ & $59.8(27.3)$ & $33.0-132.0$ & 250 & NA \\
\hline $\mathrm{SO}_{4}{ }^{2-}(\mathrm{mg} / \mathrm{L})$ & $17.1(8.7)$ & $8.0-48.0$ & 200 & NA \\
\hline $\mathrm{HCO}_{3}-(\mathrm{mg} / \mathrm{L})$ & $246(8.8)$ & $226.0-259.0$ & NA & NA \\
\hline $\mathrm{NO}_{3}{ }^{-}(\mathrm{mg} / \mathrm{L})$ & $21.5(10.9)$ & $0.0-46.2$ & 50 & 50 \\
\hline $\mathrm{PO}_{4}{ }^{3-}(\mathrm{mg} / \mathrm{L}$ as $\mathrm{P})$ & $0.8(0.7)$ & $0.0-3.0$ & NA & NA \\
\hline $\mathrm{Ca}^{2+}(\mathrm{mg} / \mathrm{L})$ & $50.7(3.3)$ & $46.0-59.0$ & 100 & NA \\
\hline $\mathrm{Mg}^{2+}(\mathrm{mg} / \mathrm{L})$ & $20.0(1.7)$ & $17.0-25.0$ & 100 & NA \\
\hline $\mathrm{Na}^{+}(\mathrm{mg} / \mathrm{L})$ & $39.8(18.8)$ & 21-91 & 200 & NA \\
\hline $\mathrm{K}^{+}(\mathrm{mg} / \mathrm{L})$ & $2.7(4.5)$ & $0-19$ & 10 & NA \\
\hline $\mathrm{NH}_{4}{ }^{+}(\mathrm{mg} / \mathrm{L}$ as $\mathrm{N})$ & $1.6(2.4)$ & $0.0-8.5$ & NA & NA \\
\hline $\mathrm{TH}\left(\mathrm{mg} / \mathrm{L}\right.$ as $\left.\mathrm{CaCO}_{3}\right)$ & $208.5(13.4)$ & $187.2-250.0$ & 500 & \\
\hline DO $(\mathrm{mg} / \mathrm{L})$ & $7.9(0.6)$ & $6.8-9.3$ & NA & NA \\
\hline $\mathrm{TOC}(\mathrm{mg} / \mathrm{L})$ & $0.3(1)$ & $0.0-5.3$ & 80 & NA \\
\hline
\end{tabular}

+ TDS: Total dissolved solids; TH: Total hardness; DO: dissolved oxygen; TOC: total organic carbon. 


\subsection{1. $\mathrm{pH}$, Total Dissolved Solids and Dissolved Oxygen}

The results presented in Table 1 reveal that groundwater in the West Bank is neutral to slightly alkaline and contains oxygen. Dissolution of metals from bedrock is, consequently, not expected to be very high. The TDS of groundwater is mainly due to the presence of inorganic salts. Groundwater from all wells included in the study has low TDS, far below the maximal values defined by the Palestinian drinking water standards. The TDS concentration in the upper aquifer is significantly higher $(p<0.05)$ than in the lower (average $370 \mathrm{mg} / \mathrm{L}$ with STD $55 \mathrm{mg} / \mathrm{L}$ and $301 \mathrm{mg} / \mathrm{L}$ with STD $28 \mathrm{mg} / \mathrm{L}$, respectively). TDS could have either geogenic origin, which is controlled by the characteristics of the bedrock, or is a consequence of anthropogenic activities, including urban runoffs, disposal of municipal and industrial wastewaters, etc. [1]. It is likely that higher TDS of groundwater of the upper aquifer is as a consequence of anthropogenic activities, since the bedrock of both aquifers is similar.

\subsubsection{Chloride and Sodium}

The chloride concentrations in all groundwater samples included in this study were from 33 to $132 \mathrm{mg} / \mathrm{L}$, significantly below the guideline value of $250 \mathrm{mg} / \mathrm{L}$ proposed by the Palestinian drinking water standards.

Chloride ions in groundwater mainly originate from soluble chloride salts, which are found in different minerals, and released into the groundwater [1]. Elevated concentrations of $\mathrm{Na}^{+}$and $\mathrm{Cl}^{-}$in the water of most of the investigated wells strongly suggest that another source, in addition to geology, is likely present. Since the wells are abstracting water far away from the coastal area, sea water intrusion is not very likely. Possible non geogenic sources of $\mathrm{Na}^{+}$and $\mathrm{Cl}^{-}$ions could be intensive use of fertilizers, and discharge of municipal wastewater. However, an additional investigation on fertilizers used in the West Bank should be conducted to verify possible link with ground water quality.

Peri-urban areas are often characterized by heavily compromised groundwater quality, with excess levels of chloride [1,25]. Chloride has been investigated as a chemical indicator of groundwater contamination by sewage because of high chlorite concentration in excreta, and its mobility in the subsurface [26,27]. The cesspits are widely spread over the West Bank [28], and the uncontrolled random disposal of the emptied septage in wadis is a common practice. In addition, wadis that receive untreated sewage are expected to be major groundwater pollution sources (Figure 2).

\subsubsection{Fluoride}

The concentration of fluoride in groundwater from all wells included in this study is lower than the Palestinian standards and the WHO guideline value of $1.5 \mathrm{mg} / \mathrm{L}$ (Table 1). This shows that groundwater quality in the West Bank is different from that in the Gaza Strip, where fluoride in groundwater is present at higher concentrations [18]. It is also known that symptoms of dental fluorosis can be more frequently observed in population from the Gaza Strip in comparison to the West Bank. The difference could be attributed to the dissimilar geological structures, and proximity of Gaza Strip to the Mediterranean Sea, that results in sea water intrusion. Some fluoride $(0.1$ to $1.2 \mathrm{mg} / \mathrm{L})$ was, however, present in all groundwater samples from wells included in the study. Presence of fluoride in drinking water at concentration of up to approximately $1.0 \mathrm{mg} / \mathrm{L}$ contributes to dental health of the population [29]. Fluoride is usually naturally occurring in groundwater as a result of weathering and dissolution of fluoride containing rocks including fluorite, fluor apatite, silicates, and volcanic ash [30]. The most common mineral found in weathered sedimentary phosphorites belongs to the apatite mineral group. Francolite, $\mathrm{Ca}_{10-\mathrm{a}-\mathrm{b}} \mathrm{Na}_{\mathrm{a}} \mathrm{Mg}_{\mathrm{b}}\left(\mathrm{PO}_{4}\right)_{6-\mathrm{x}}\left(\mathrm{CO}_{3}\right)_{\mathrm{x}-\mathrm{y}-\mathrm{z}}\left(\mathrm{CO}_{3} \mathrm{~F}\right)_{\mathrm{y}}\left(\mathrm{SO}_{4}\right)_{\mathrm{z}} \mathrm{F}_{2}$, a carbonate rich variety of the mineral fluorapatite, is present in Palestine [31,32]. Fluoride could also be released into the groundwater due to the application of phosphorous fertilizers $[33,34]$. Based on results from a study on quality of wastewater from the Al-Bireh city (unpublished), fluoride concentration of $2.7 \mathrm{mg} / \mathrm{L}$ might also be present in municipal wastewater and can consequently 
contribute to fluoride concentration in groundwater. The source of fluoride in wastewater might be toothpaste since sodium fluoride $(\mathrm{NaF})$ is added in most toothpaste as a dental aid, and industrial wastewater, due to hydrofluoric acid (HF), the most common source of fluoride used by industry.

\subsubsection{Sulphate}

The sulphate $\left(\mathrm{SO}_{4}{ }^{2-}\right)$ concentrations in all samples were far below the maximal acceptable level defined by the Palestinian drinking water standards of $200 \mathrm{mg} / \mathrm{L}$ (Table 1). The situation in Gaza is different where much higher chloride and sulphate concentrations have been reported [18], mainly due to seawater intrusion. Since groundwater in the West Bank is aerobic, rather low sulphate concentrations cannot be attributed to inhibition of sulphide oxidation [1,35]. Indeed, chloride and sulphate are abundant in sedimentary rocks [33]. The presence of chloride and sulphate in the West Bank groundwater could be, consequently, partially attributed to the geological structure of the subsoil characterized by presence of sedimentary rock.

\subsubsection{Total Hardness, Calcium, Magnesium}

As shown in Table 1, the Total Hardness (TH) of all groundwater samples was below the maximal acceptable value defined by the Palestinian Standard for drinking water. Nevertheless, the groundwater in the study area can be characterized as relatively hard. Depending on the interaction of other factors, such as $\mathrm{pH}$ and alkalinity, water with a hardness above approximately $200 \mathrm{mg} / \mathrm{L}$ (as $\mathrm{CaCO}_{3}$ ) may cause scale deposition in the treatment works, distribution system, pipes, tanks and water heaters within buildings $[24,36]$.

Hardness is strongly influenced by the geological structure of the aquifer, and usually hard water is found in areas where limestone formations are present [37], as in the West Bank. Hardness of groundwater samples included in this study can be attributed to calcium for approximately $60 \%$. The presence of magnesium $\left(\mathrm{Mg}^{2+}\right)$, which, together with calcium $\left(\mathrm{Ca}^{2+}\right)$, has beneficial effect on human health [38], is likely due to wide presence of dolomite. Ground water is also well buffered with $\mathrm{HCO}_{3}{ }^{-}$. The ground water quality and specifically high concentrations of $\mathrm{HCO}_{3}{ }^{-}$and $\mathrm{Ca}^{2+}$ reflect the nature of the carbonate aquifers as will be shown hereafter.

\subsubsection{Ammonium and Nitrate}

The nitrate $\left(\mathrm{NO}_{3}{ }^{-}\right)$concentration in groundwater samples from all wells included in this study, with the exception of one well in Tulkarem, did not exceed $30 \mathrm{mg} / \mathrm{L}$. The well in Tulkarem abstracting water from the Upper Cenomanian aquifer, showed nitrate concentration of $46 \mathrm{mg} / \mathrm{L}$, approaching the maximal acceptable level of $50 \mathrm{mg} / \mathrm{L}$. Nitrate has been considered as a chemical indicator of groundwater contamination by sewage because of high nitrate concentrations in excreta, and its mobility in the subsurface [26,27]. Presence of elevated concentrations of nitrate in most of wells included in this study is of special concern, given the adverse health effects and very complex and expensive treatment required for its removal. In addition to nitrate, nitrite has very similar adverse effect on human health, however, at much lower concentrations [24]. If elevated nitrate concentrations in groundwater are (partially) caused by uncontrolled discharge of domestic wastewater [25], presence of nitrite, an intermittent product of ammonium oxidation to nitrate, cannot be excluded. Concentrations of nitrite were, however, not analyzed in this study. It is consequently strongly recommended to continue monitoring of nitrate levels in groundwater, including possible presence of nitrite in wells used for drinking water supply.

Relatively high to very high concentrations of ammonium (from 1.1 to $8.5 \mathrm{mg} \mathrm{N} / \mathrm{L}$ ) were found in 12 wells, while other wells included in the study had concentrations below the detection limit. Wells with high ammonium concentration are located close to wastewater disposal wadis, and/or solid waste duping sites (Figure 2). Groundwater in urban areas is often characterized by excess levels of nitrogenous compounds [25]. Presence of ammonium in $t$ groundwater, suggests that transport of the pollution to groundwater is very fast. The 
karstic nature of the aquifer could result in very fast transport of the pollution to wells used for water supply. High levels of ammonium found in approximately $50 \%$ of the wells is of serious concern, having in mind that groundwater is used as a drinking water after chlorination only, without any other treatment. It is known that presence of ammonium could compromise the effectiveness of chlorination due to formation of less effective chloramines. Alternatively, very high dosages of chlorine are required to fully transform ammonium to nitrogen gas. High dosages of chlorine could result in formation of health hazardous oxidation products, e.g., THMs. Presence of relatively high to very high levels of phosphate $(0.8-6.0 \mathrm{mg} \mathrm{P} / \mathrm{L})$ in 20 wells, additionally confirmed that groundwater pollution with untreated, or insufficiently treated wastewater very likely takes place.

Additional research should be conducted to verify possible source(s) of nitrate and ammonium pollution, and propose measures that will prevent, or at least reduce, further deterioration of groundwater quality. Furthermore, treatment of groundwater from wells with elevated ammonium concentration is required to improve drinking water quality and enhance effectiveness of disinfection with chlorine.

\subsubsection{Heavy Metals}

The concentrations of most heavy metals analyzed (e.g., $\mathrm{Cr}, \mathrm{Cu}, \mathrm{Mn}, \mathrm{Pb}, \mathrm{Cd}$, and As) in all the analyzed samples were found to be below the detection limit of the analytical methods applied. Dissolved iron was found in two samples at concentrations of 0.1 and $0.6 \mathrm{mg} / \mathrm{L}$, likely due to anoxic conditions created in a part of the aquifer due to uncontrolled wastewater discharge, and associated dissolution of iron containing minerals.

\subsubsection{Microbiology}

Groundwater samples collected in this study were free from fecal coliforms, regardless of the karst features of the aquifers systems. In general, groundwater in urban areas is often characterized by presence of pathogens [25]. Presence of pathogens in karstic aquifers is, however, strongly influenced by local conditions including travel time, depth of the well, geology, etc. Ghanem et al. [39] reported fecal coliform pollution of water from springs in the West Bank that was attributed to contamination by wastewater leaking from cesspits in the vicinity, as well as due to manure piles located near some springs that are fed by shallow groundwater. The absence of microbial pollution in deep groundwater wells, that were included in this study, might be due to composition and filtering effect of the topsoil layers that resulted in die-off of micro-organisms.

\subsection{Correlation between Different Water Quality Parameters}

The correlation coefficients (Table 2) show that there is significant correlation between $\mathrm{Na}^{+}$and $\mathrm{Cl}^{-}, \mathrm{Na}^{+}$and TDS, $\mathrm{Cl}^{-}$and TDS, and $\mathrm{Ca}^{2+}$ and $\mathrm{Mg}^{2+}$. Strong correlation between $\mathrm{Ca}^{2+}$ and $\mathrm{Mg}^{2+}$ suggests that dissolution of dolomite is their predominant source.

Table 2. Correlation matrix of the different parameters analyzed for the samples of groundwater from drinking water wells in the West Bank/Palestine.

\begin{tabular}{cccccccccc}
\hline & TDS & $\mathbf{C a}^{2+}$ & $\mathbf{M g}^{2+}$ & $\mathbf{N a}^{+}$ & $\mathbf{H C O}^{3-}$ & $\mathbf{C l}^{-}$ & $\mathbf{S O}_{4}{ }^{2-}$ & $\mathbf{N O}_{3}{ }^{-}$ & Depth \\
\hline $\mathrm{TDS}$ & 1 & & & & & & & & \\
$\mathrm{Ca}^{2+}$ & 0.23 & 1.00 & & & & & & & \\
$\mathrm{Mg}^{2+}$ & 0.40 & 0.60 & 1.00 & & & & & & \\
$\mathrm{Na}^{+}$ & 0.91 & 0.14 & 0.25 & 1.00 & & & & & \\
$\mathrm{HCO}_{3}{ }^{-}$ & 0.17 & 0.39 & 0.37 & 0.13 & 1.00 & & & & \\
$\mathrm{Cl}^{-}$ & 0.92 & 0.16 & 0.26 & 0.99 & 0.16 & 1.00 & & & \\
$\mathrm{SO}_{4}{ }^{2-}$ & 0.14 & 0.05 & 0.19 & 0.03 & 0.08 & 0.03 & 1.00 & & \\
$\mathrm{NO}_{3}{ }^{-}$ & 0.28 & 0.17 & 0.04 & 0.20 & -0.29 & 0.21 & -0.22 & 1.00 & \\
Depth & -0.50 & -0.34 & -0.27 & -0.39 & 0.04 & -0.39 & -0.16 & -0.48 & 1 \\
\hline
\end{tabular}


The wells tapping the Lower Cenomanian aquifer show significantly lower $\mathrm{Na}^{+}$, $\mathrm{Cl}^{-}$, and TDS $(p<0.05)$ in comparison with the Upper Cenomanian aquifer (Table 3). This finding is opposite to expected increase of salt concentrations with depth [40,41], a consequence of natural processes, e.g., dissolution and leaching of the aquifer minerals. Therefore, the source of elevated salts concentration in the Upper Cernomanian aquifer is most likely not only due to natural, geogenic processes, but is presumably also caused by human activities, such as uncontrolled wastewater disposal or intensive use of fertilizers. The Lower Cenomanian aquifer shows fewer signs of contamination because the aquifer is mostly covered with a confining layer of the Yatta Formation. The confining layer will, however, not completely retain $\mathrm{Cl}^{-}$and $\mathrm{Na}^{+}$and nitrate, and, consequently, they reach the groundwater, in limited quantities, with percolated (waste) water.

Table 3. Depth, groundwater quality, and water type for selected domestic wells tapping the Upper and the Lower Cenomanian aquifers in the West Bank/Palestine.

\begin{tabular}{|c|c|c|c|c|c|c|c|c|c|c|c|c|}
\hline \multirow[b]{2}{*}{ Well Code } & \multicolumn{12}{|c|}{ Upper Cenomanian Aquifer } \\
\hline & Depth & $\mathrm{pH}$ & Water Type & $\mathrm{Ca}^{2+}$ & $\mathrm{Mg}^{2+}$ & $\mathrm{Na}^{+}$ & $\mathbf{K}^{+}$ & $\mathrm{HCO}_{3}^{-}$ & $\mathrm{Cl}^{-}$ & $\mathrm{SO}_{4}^{2-}$ & $\mathrm{NO}_{3}^{-}$ & TDS \\
\hline $18-8 / 038$ & 413 & 7.1 & $\mathrm{Ca}-\mathrm{Mg}-\mathrm{Na}-\mathrm{HCO}_{3}-\mathrm{Cl}$ & 48 & 21 & 33 & 8 & 246 & 51 & 12 & 11 & 397 \\
\hline 16-19/002 & 200 & 7.2 & $\mathrm{Na}-\mathrm{Ca}-\mathrm{HCO}_{3}-\mathrm{Cl}$ & 53 & 18 & 68 & 5 & 245 & 98 & 28 & 26 & 419 \\
\hline 17-20/051A & 370 & 6.9 & $\mathrm{Ca}-\mathrm{Na}-\mathrm{Mg}-\mathrm{HCO}_{3}-\mathrm{Cl}$ & 46 & 21 & 40 & 7 & 247 & 58 & 31 & 26 & 353 \\
\hline $16-11 / 001 \mathrm{~A}$ & 305 & 7.3 & $\mathrm{Ca}-\mathrm{Mg}-\mathrm{Na}-\mathrm{HCO}_{3}$ & 47 & 18 & 25 & 0 & 243 & 36 & 13 & 11 & 271 \\
\hline 15-19/047 & 188 & 7.1 & $\mathrm{Ca}-\mathrm{Mg}-\mathrm{Na}-\mathrm{HCO}_{3}-\mathrm{Cl}$ & 52 & 20 & 36 & 0 & 252 & 55 & 21 & 19 & 329 \\
\hline 18-15/001 & 61 & 7.1 & $\mathrm{Ca}-\mathrm{Mg}-\mathrm{Na}-\mathrm{HCO}_{3}-\mathrm{Cl}$ & 51 & 19 & 30 & 7 & 248 & 43 & 12 & 24 & 310 \\
\hline $14-17 / 052$ & 142 & 7.3 & $\mathrm{Na}-\mathrm{Ca}-\mathrm{Mg}-\mathrm{HCO}_{3}-\mathrm{Cl}$ & 53 & 21 & 84 & 0 & 255 & 124 & 15 & 24 & 449 \\
\hline 15-18/012 & 163 & 7.2 & $\mathrm{Ca}-\mathrm{Mg}-\mathrm{Na}-\mathrm{HCO}_{3}-\mathrm{Cl}$ & 59 & 25 & 45 & 1 & 240 & 66 & 16 & 28 & 360 \\
\hline $17-20 / 050 Q$ & 686 & 7.4 & $\mathrm{Na}-\mathrm{Ca}-\mathrm{Mg}-\mathrm{HCO}_{3}-\mathrm{Cl}$ & 50 & 21 & 91 & 0 & 254 & 132 & 13 & 0 & 434 \\
\hline $15-20 / 008$ & 176 & 7.0 & $\mathrm{Ca}-\mathrm{Na}-\mathrm{Mg}-\mathrm{HCO}_{3}-\mathrm{Cl}$ & 50 & 20 & 57 & 0 & 242 & 88 & 12 & 42 & 390 \\
\hline 14-17/051 & 177 & 7.4 & $\mathrm{Ca}-\mathrm{Mg}-\mathrm{Na}-\mathrm{HCO}_{3}-\mathrm{Cl}$ & 58 & 22 & 38 & 0 & 256 & 59 & 31 & 26 & 362 \\
\hline 16-19/012 & 466 & 7.1 & $\mathrm{Ca}-\mathrm{Mg}-\mathrm{Na}-\mathrm{HCO}_{3}-\mathrm{Cl}$ & 47 & 17 & 32 & 0 & 226 & 49 & 18 & 28 & 304 \\
\hline $15-19 / 046$ & 201 & 6.9 & $\mathrm{Na}-\mathrm{Ca}-\mathrm{Mg}-\mathrm{HCO}_{3}-\mathrm{Cl}$ & 49 & 21 & 72 & 0 & 246 & 112 & 19 & 46 & 442 \\
\hline \multirow[t]{2}{*}{$15-19 / 010$} & 262 & 7.3 & $\mathrm{Ca}-\mathrm{Na}-\mathrm{Mg}-\mathrm{HCO}_{3}-\mathrm{Cl}$ & 52 & 18 & 50 & 0 & 244 & 75 & 13 & 28 & 358 \\
\hline & \multicolumn{12}{|c|}{ Lower Cenomanian Aquifer } \\
\hline $16-11 / 008$ & 704 & 7.25 & $\mathrm{Ca}-\mathrm{Mg}-\mathrm{HCO}_{3}$ & 54 & 20 & 21 & 0 & 254 & 37 & 32 & 6 & 297 \\
\hline $15-17 / 004$ & 273 & 6.86 & $\mathrm{Ca}-\mathrm{Mg}-\mathrm{Na}-\mathrm{HCO}_{3}-\mathrm{Cl}$ & 58 & 23 & 35 & 0 & 258 & 53 & 12 & 26 & 336 \\
\hline 15-19/048 & 295 & 7.2 & $\mathrm{Ca}-\mathrm{Mg}-\mathrm{Na}-\mathrm{HCO}_{3}-\mathrm{Cl}$ & 51 & 20 & 35 & 19 & 246 & 55 & 18 & 22 & 343 \\
\hline $15-09 / 013$ & 495 & 7.27 & $\mathrm{Ca}-\mathrm{Mg}-\mathrm{Na}-\mathrm{HCO}_{3}-\mathrm{Cl}$ & 48 & 21 & 36 & 8 & 238 & 55 & 48 & 4 & 339 \\
\hline $16-18 / 003 \mathrm{~A}$ & 670 & 7.42 & $\mathrm{Ca}-\mathrm{Mg}-\mathrm{HCO}_{3}$ & 51 & 19 & 21 & 6 & 258 & 33 & 19 & 22 & 300 \\
\hline $18-15 / 006$ & 616 & 7.15 & $\mathrm{Ca}-\mathrm{Mg}-\mathrm{Na}-\mathrm{HCO}_{3}-\mathrm{Cl}$ & 48 & 18 & 25 & 3 & 230 & 38 & 8 & 23 & 278 \\
\hline $16-12 / 004$ & 672 & 7.32 & $\mathrm{Ca}-\mathrm{Mg}-\mathrm{HCO}_{3}-\mathrm{Cl}$ & 51 & 19 & 23 & 0 & 241 & 38 & 12 & 19 & 283 \\
\hline 17-17/003 & 525 & 7.87 & $\mathrm{Ca}-\mathrm{Mg}-\mathrm{HCO}_{3}$ & 47 & 18 & 23 & 2 & 228 & 34 & 11 & 19 & 268 \\
\hline $17-12 / 007$ & 741 & 7.09 & $\mathrm{Ca}-\mathrm{Mg}-\mathrm{HCO}_{3}$ & 49 & 20 & 22 & 0 & 274 & 38 & 14 & 3 & 265 \\
\hline 17-17/004 & 675 & 7.25 & $\mathrm{Ca}-\mathrm{Mg}-\mathrm{Na}-\mathrm{HCO}_{3}$ & 48 & 20 & 31 & 0 & 236 & 38 & 17 & 25 & 297 \\
\hline 15-15/004 & 510 & 7.58 & $\mathrm{Ca}-\mathrm{Mg}-\mathrm{HCO}_{3}$ & 52 & 20 & 23 & 11 & 244 & 38 & 10 & 30 & 306 \\
\hline
\end{tabular}

Well depth is an important factor that can influence the degree of contamination. As an example, the relatively shallow well of Tulkarem (ID: 15-19/046; depth $201 \mathrm{~m}$ ) tapping the Upper Cenomanian aquifer, shows clear signs of contamination with nitrate, with concentrations of $46 \mathrm{mg} / \mathrm{L}$. The well lies along the wastewater stream of more than $4000 \mathrm{~m}^{3}$ /day in Wadi Zeimar flowing from Nablus to Tulkarem city (Figure 2). The deep Deir Sharaf 2a well (ID: 16-18/003A; depth 670 m), tapping the Lower Cenomanian aquifer, which lies close to the same stream, taps ground water with much lower nitrate concentration $(21.7 \mathrm{mg} / \mathrm{L})$. In general, the deepest wells ( $>600 \mathrm{~m}$ depth) of the Lower Cenomanian aquifer were found to be less contaminated, and have the lowest $\mathrm{Cl}^{-}, \mathrm{Na}^{+}$, and TDS. Another example is the Azzun well (ID: 15-17/004; depth $273 \mathrm{~m}$ ) that shows clear signs of nitrate contamination, with a concentration of $26 \mathrm{mg} / \mathrm{L}$. This well lies in agricultural area, and the nearby villages still use cesspits for sewage disposal, that can both be sources of nitrate. The average $\mathrm{NO}_{3}{ }^{-}$concentration in the Lower Cenomanian aquifer of $18 \mathrm{mg} / \mathrm{L}$ was lower than the upper of $24 \mathrm{mg} / \mathrm{L}(p<0.06)$. The correlation coefficient between the $\mathrm{NO}_{3}{ }^{-}$and depth, for all analyzed wells, shows a moderate negative 
correlation (correlation coefficient -0.50). The correlation between nitrate and well depth was higher for the upper aquifer $(-0.60)$, but very low for the lower aquifers $(-0.12)$. In general, the nitrate concentration in groundwater is known to decrease with depth [42].

\subsection{Groundwater Types}

\subsubsection{Durov Diagram}

Groundwater from wells tapping the mountain aquifer that were included in this study is likely a mixture of two water sources, as shown in Figure 4. Groundwater quality data of wells of the mountain aquifer included in this study are lying on the diagonal line connecting the quality of groundwater samples of uncontaminated Cenomanian aquifer (left-lower corner) with the points representing domestic wastewater (right-upper corner). This strongly suggests that a mixing of wastewater and fresh, uncontaminated groundwater takes place.

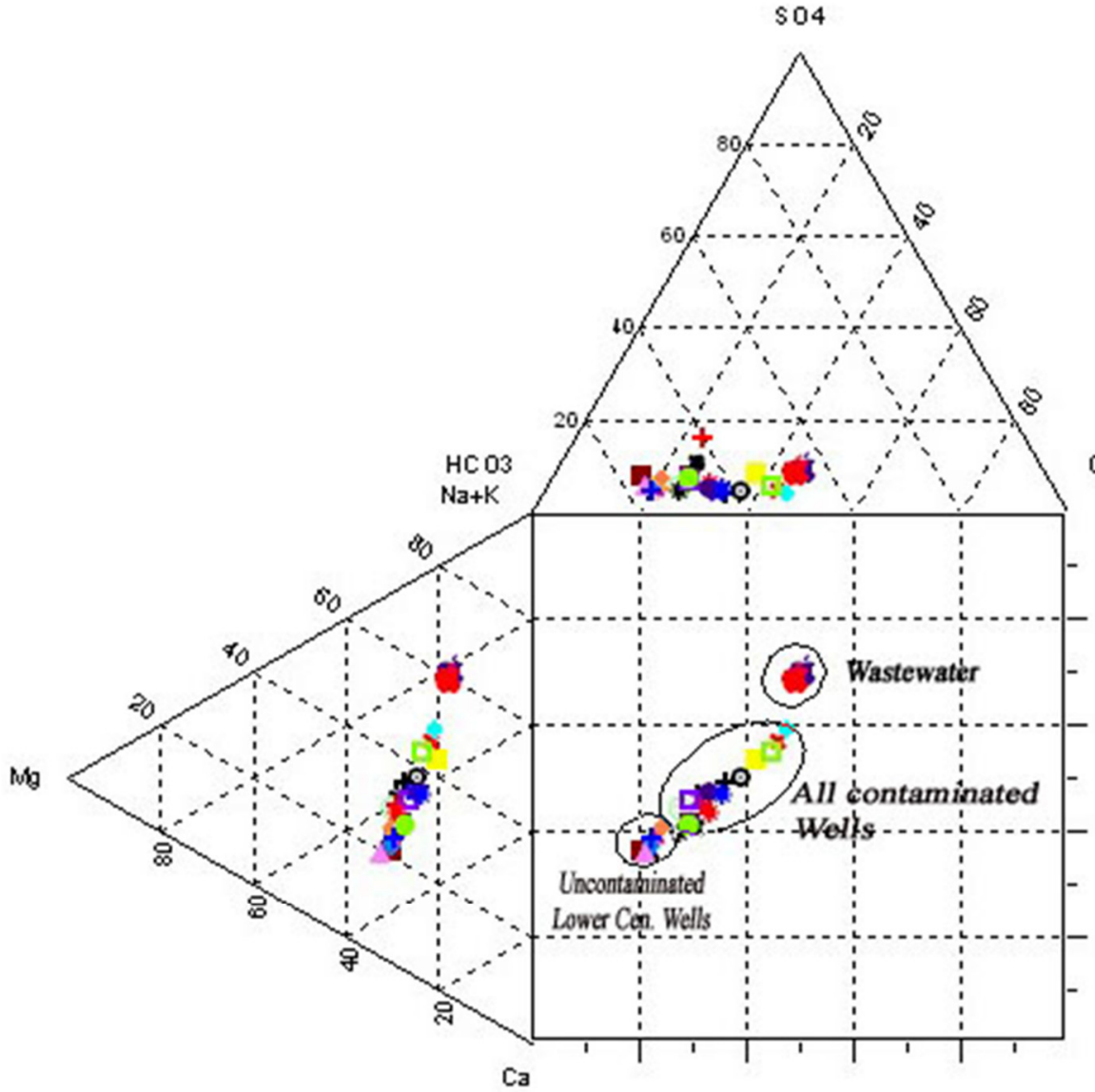

\begin{tabular}{|c|c|}
\hline \multicolumn{2}{|c|}{ Lege id } \\
\hline * & $15-17.004$ \\
\hline 0 & $16-11.001 \mathrm{~A}$ \\
\hline ○ & $15-20.008$ \\
\hline 口 & $15-19.048$ \\
\hline 口 & $15-19.067$ \\
\hline 므 & $15-19.046$ \\
\hline + & $15-18.012$ \\
\hline 口 & $16-18.002 \mathrm{~A}$ \\
\hline+ & $15-15.00 \mathrm{l}$ \\
\hline+ & $15-09.013$ \\
\hline+ & $15-09.012 ?$ \\
\hline$x$ & $15-09.012$ \\
\hline$x$ & $14-17.052$ \\
\hline$x$ & $16-17.051$ \\
\hline * & $15-19.010$ \\
\hline$\bullet$ & $17-17.003$ \\
\hline & $W$ adi $N$ ar 2 \\
\hline 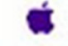 & $W$ adı $n$ ar 1 \\
\hline$(3)$ & $18-18038$ \\
\hline$*$ & $18-15.006$ \\
\hline$\Rightarrow$ & $18-15.001$ \\
\hline 4 & $17-20.051 \mathrm{~A}$ \\
\hline$\bullet$ & $17-17.004$ \\
\hline$\bullet$ & $17-12.011$ \\
\hline $\boldsymbol{\Delta}$ & $17-12.010$ \\
\hline$\Delta$ & $17-12,007$ \\
\hline ○ & $16-20.006$ \\
\hline e & $16-19.012$ \\
\hline 마 & $16-19.002$ \\
\hline 암 & $17-20.0500$ \\
\hline
\end{tabular}

Figure 4. Durov diagram for domestic wells included in the study, tapping the mountain aquifer in the West Bank, and wastewater (Legend stands for a well ID).

\subsubsection{Piper Diagram}

Piper diagram was plotted for wells included in this study to classify the groundwater types (Figure 5). The water types are presented in Table 3. The major water types of groundwater from wells included in the study are: 
1. Earth alkaline water with prevailing bicarbonate $\left(\mathrm{Ca}-\mathrm{Mg}-\mathrm{HCO}_{3}\right)$.

2. Earth alkaline water with increased portion of alkalis and prevailing bicarbonate (Ca-Mg-Na- $\mathrm{HCO}_{3}$ or $\left.\mathrm{Ca}-\mathrm{Mg}-\mathrm{HCO}_{3}-\mathrm{Cl}\right)$.

3. Alkaline water with prevailing bicarbonate and alkaline water with prevailing chloride $\left(\mathrm{Na}-\mathrm{Ca}-\mathrm{Mg}-\mathrm{HCO}_{3}-\mathrm{Cl}\right.$ or $\left.\mathrm{Na}-\mathrm{Ca}-\mathrm{HCO}_{3}-\mathrm{Cl}\right)$.

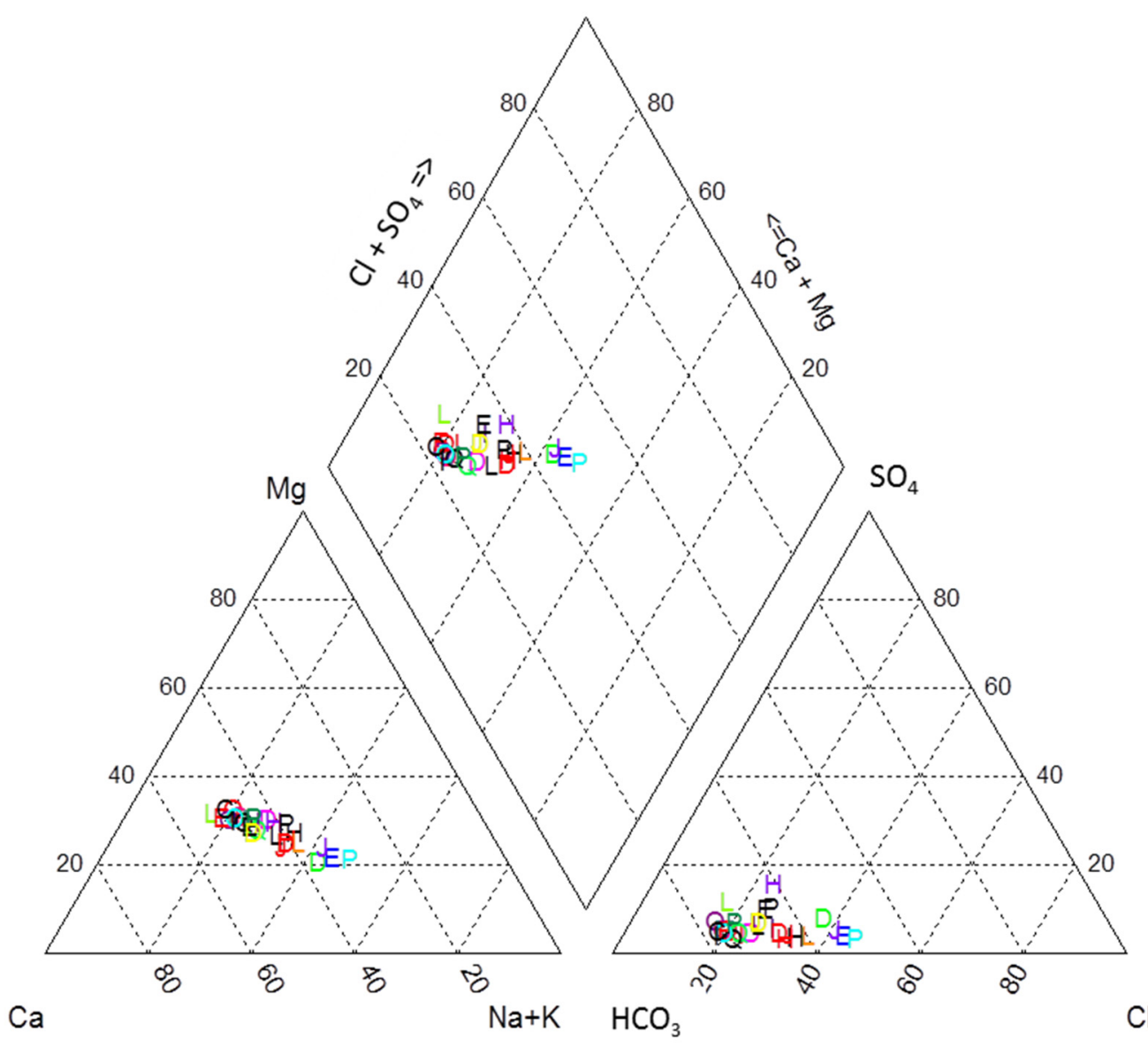
Legend
E 16-12/004
E 14-17/051
E 14-17/052
H 15-09/012
H 15-09/012?
H $15-09 / 013$
I 15-15/004
I 15-17/004
| 15-18/012
J 15-19/010
J 15-19/046 15-19/047
L $\quad 15-19 / 048$
$+\quad 15-20 / 008$
L 16-11/008
Q $17-12 / 010$
Q 18-15/006
Q 18-15/001
P $\quad 17-20 / 051 \mathrm{~A}$
P $17-20 / 050 \mathrm{Q}$
P 17-17/004
M 16-11/001A
O $17-12 / 011$
D $18-18038$
C $17-12 / 007$
D $16-20 / 006$ 16-19/012
D 16-19/002
O $16-18 / 003 \mathrm{~A}$
- 17-17/003

Figure 5. Piper diagram for domestic wells included in the study, tapping the mountain aquifer in the West Bank/Palestine (Legend stands for a well ID).

The original water is the natural recharge water from which other water types are derived by different processes, including mixing with another water type, and dissolution of mineral phases from the aquifer. The $\mathrm{Ca}-\mathrm{Mg}-\mathrm{HCO}_{3}$ water type is the recharge water, common for especially carbonate aquifers [39]. The type 2 water (Ca-Mg-Na- $-\mathrm{HCO}_{3}$ or $\mathrm{Ca}-\mathrm{Mg}-\mathrm{HCO}_{3}-\mathrm{Cl}$ ) is the most abundant water type among the domestic wells in the West Bank, representing more than 15 wells included in this study. This water type originates from the type 1 water after mixing with another water type, and leaching and dissolution of the aquifer material. The type 3 water ( $\mathrm{Na}-\mathrm{Ca}-\mathrm{Mg}-\mathrm{HCO}_{3}-\mathrm{Cl}$ or $\mathrm{Na}-\mathrm{Ca}-\mathrm{HCO}_{3}-\mathrm{Cl}$ ) is the most extreme water type found in the domestic wells in the West Bank, that show the highest TDS, $\mathrm{Cl}^{-}$and $\mathrm{Na}^{+}$concentrations. 


\subsubsection{Dry vs. Wet Seasons}

Most of the groundwater samples included in this study were taken during the dry season. In order to assess possible effect of rain on the groundwater quality, a number of groundwater samples were also taken from seven wells during the rainy season. The results presented in Table 4 show ammonium and nitrate concentration in samples taken from selected wells during both dry and the rainy season.

Table 4. Ammonium and nitrate concentration in selected wells during dry and wet seasons.

\begin{tabular}{ccccc}
\hline Well Name & \multicolumn{2}{c}{$\mathbf{N H}_{4}{ }^{+}-\mathbf{N}$} & \multicolumn{2}{c}{$\mathrm{NO}_{3}{ }^{-}$} \\
\hline & Dry Season & Rainy Season & Dry Season & Rainy Season \\
\hline Deir Alghsoon & 7.8 & 0.4 & 18.9 & 15.4 \\
Qabatia & 0 & 0.5 & 0 & 5.7 \\
Tulkarem & 0 & 0 & 46.2 & 44 \\
Habla & 0 & 0.5 & 23.5 & 15 \\
Balaa & 7 & 0.4 & 21.5 & 20 \\
Araba & 0 & 0 & 26.4 & 18.4 \\
Deir Sharaf & 8.5 & 3.8 & 21.7 & 10.5 \\
\hline Avg. (STD) & $3.3(4.2)$ & $0.8(1.3)$ & $23(13.5)$ & $18.4(12)$ \\
\hline Range & $0-8.5$ & $0-3.8$ & $0-46.2$ & $5.7-20$ \\
\hline
\end{tabular}

Concentrations of nitrate, and, more strongly, ammonium were reduced during the rainy season. Reduction of nitrate and ammonium concentration is presumably due to dilution of infiltrated wastewater with rainwater. Results obtained also suggest that quality of groundwater, in terms of ammonium and nitrate, will slowly be naturally improved if the groundwater pollution is stopped. The fecal coliforms were absent also in groundwater samples taken during rainy season.

\section{Conclusions}

The water quality analyses of groundwater samples conducted in this study, suggest that majority of wells can be used for water supply after proper disinfection, based on requirements prescribed by the WHO drinking water quality guideline and Palestinian drinking water quality standards. The main conclusions of this study are:

1. The concentration of heavy metals (e.g., $\mathrm{Cr}, \mathrm{Cu}, \mathrm{Mn}, \mathrm{Pb}, \mathrm{Cd}$, and $\mathrm{As}$ ) in all samples analyzed are found to be below the detection limit.

2. Elevated nitrate, ammonium, chloride, and sodium concentrations are, however, observed in wells tapping both Upper and Lower Cenomanian, including some deep wells tapping from the confined Lower Cenomanian aquifer.

3. Elevated concentrations of nitrate, with concentrations in some wells approaching the maximal acceptable level of $50 \mathrm{mg} / \mathrm{L}$, together with high levels of ammonium in approximately half of the wells, is of a serious concern and could introduce severe problems in the future, that can threaten safe drinking water supply in parts of West Bank. Groundwater from wells with high ammonium, and in some cases elevated iron, concentrations should be treated to allow more effective disinfection with chlorine and improve aesthetic quality of drinking water. Additional groundwater sampling and water quality analyses should be done to identify possible presence of nitrite in groundwater given its combined adverse health effect with nitrate.

4. The source of groundwater pollution is likely caused by uncontrolled disposal of untreated wastewater and/or agricultural activities. High concentration of ammonium in approximately half of the wells included in this study supports this hypothesis.

5. Groundwater quality appropriate for drinking water supply cannot be guaranteed in the future, unless proper environmental management of the sources of pollution is put in place, to assure sustainable availability of this fresh water source also in the future. Further water quality studies are recommended to provide more sampling 
and/or data points over a period of time. Availability of water quality monitoring data for a few years are very useful to compare the correlations between population, any infiltration from external sources and any other factors that are contributing to the variations in the concentrations of different ions.

Author Contributions: Conceptualization, N.M. and B.P.; methodology, N.M. and B.P.; sofware, O.Z.; validation, N.M. and B.P.; formal analysis, N.M. and B.P.; investigation, N.M. and O.Z.; resources, N.M.; data curation, O.Z.; writing-original draft preparation, N.M.; writing-review and editing, B.P.; visualization, N.M. and O.Z.; funding acquisition, N.M. and B.P. All authors have read and agreed to the published version of the manuscript.

Funding: This research was funded by the Dutch Ministry of Foreign Affairs (DGIS) through the IHE Delft Partnership Research Fund (UPaRF) grant number OD/190/VDO. The APC was funded by the Dutch Ministry of Foreign Affairs (DGIS) grant number 2020/037/106808/EWH, titled "DUPC2 GW DEMO".

Acknowledgments: This study was a part of the HYDRAS project implemented jointly by Birzeit University (Palestine), Blas Pascal University (Argentina), and IHE Delft (The Netherlands). The financial support provided by the IHE Delft Partnership Research Fund (UPaRF) is highly appreciated.

Conflicts of Interest: The authors declare no conflict of interest.

\section{References}

1. Shakerkhatibi, M.; Mosaferi, M.; Pourakbar, M.; Ahmadnejad, M.; Safavi, N.; Banitorab, F. Comprehensive investigation of groundwater quality in the north-west of Iran: Physicochemical and heavy metal analysis. Groundw. Sust. Develop. 2019, 8, 156-168. [CrossRef]

2. Papadopoulou, M.P.; Karatzas, G.P.; Bougioukou, G. Numerical model ling of the environmental impact of landfill leachate leakage on groundwater quality-A field application. Environ. Model. Assess. 2007, 12, 43-54. [CrossRef]

3. Lalehzari, R.; Tabatabaei, S.H.; Kholghi, M. Simulation of nitrate transport and wastewater seepage in groundwater flow system. Int. J. Environ. Sci. Technol. 2013, 10, 1367-1376. [CrossRef]

4. Nakagawa, K.; Amano, H.; Takao, Y.; Hosono, T.; Berndtsson, R. On the use of coprostanol to identify source of nitrate pollution in groundwater. J. Hydrol. 2017, 550, 663-668. [CrossRef]

5. Yuan, Y.; Liang, D.; Zhu, H. Optimal control of groundwater pollution combined with source abatement costs and taxes. J. Comp. Sci. 2017, 20, 17-29. [CrossRef]

6. Farmaki, E.G.; Thomaidis, N.S. Current status of the metal pollution of the environment of Greece-A review. Glob. NEST J. 2008, 10, 366-375.

7. Goldscheider, N.; Chen, Z.; Auler, A.S.; Bakalowicz, M.; Broda, S.; Drew, D.; Hartmann, J.; Jiang, G.; Moosdorf, N.; Stevanovic, Z.; et al. Global distribution of carbonate rocks and karst water resources. Hydrogeol. J. 2020, 28, $1661-1677$. [CrossRef]

8. Medici, G.; Smeraglia, L.; Torabi, A.; Botter, C. Review of modeling approaches to groundwater flow in deformed carbonate aquifers. Groundwater 2021, 59, 334-351. [CrossRef]

9. Palestinian Water Authority (PWA). Annual Water Status Report 2011; The Palestinian National Authority: Ramallah, Palestine, 2012.

10. Palestinian Water Authority (PWA). Water Supply Report 2010; The Palestinian National Authority: Ramallah, Palestine, 2012.

11. Ministry of Agriculture (MoA). Agricultural Sector Policy_Palestine (2017-2022); The Palestinian National Authority: Ramallah, Palestine, 2017.

12. Environment Quality Authority (EQA). Environment Sector Strategy—Executive Summary; The Palestinian National Authority: Ramallah, Palestine, 2010.

13. Goldscheider, N. Karst groundwater vulnerability mapping: Application of a new method in the Swabian Alb, Germany. Hydrogeol. J. 2005, 13, 555-564. [CrossRef]

14. Leyland, R.C. Vulnerability Mapping in Karst Terrains, Exemplified in the Wider Cradle of Humankind World Heritage Site. Master's Thesis, University of Pretoria, Pretoria, South Africa, 2008.

15. Mandal, A.; Haiduk, A. Hydrochemical characteristics of groundwater in the Kingston Basin, Kingston, Jamaica. Environ. Earth Sci. 2011, 63, 415-424. [CrossRef]

16. Qannam, Z. Environmental Status and Water Quality Evaluation of the Groundwater Resources in Bethlehem-Hebron Region/Palestine. Master's Thesis, University of Jordan, Amman, Jordan, 1997.

17. World Bank. Securing Water for Development in West Bank and Gaza; World Bank: Washington, DC, USA, 2018.

18. Abbas, M.; Barbieri, M.; Battistel, M.; Brattini, G.; Garone, A.; Parisse, B. Water Quality in the Gaza Strip: The Present Scenario. J. Water Res. Prot. 2013, 5, 54-63. [CrossRef] 
19. Petrusevski, B.; Al-Adwan, R.; Gharaibeh, M.Y.M.; Slokar, Y.M. Drinking water production from arsenic contaminated groundwater in Jordan. In Proceedings of the IWA Groundwater Specialist Conference, Belgrade, Serbia, 9-11 June 2016.

20. Rofe \& Raffety. West Bank Hydrology (1963-1965); Report for the Central Water Authority of Jordan; Westminster: London, UK, 1965.

21. American Public Health Association (APHA). Standard Methods for the Examination of Water and Wastewater; The American Public Health Association, American Water Works Association and the Water Environment Federation: Washington, DC, USA, 2012.

22. Durov, S.A. Classification of natural water and graphic representation of their composition. Doklady Ak. SSSR 1948, 59, 87-90.

23. Palestine Standards Institute (PSI). The Second Working Draft of the Amended Drinking Water Standard, Ramallah; Palestine Standards Institute: Ramallah, Palestine, 2004.

24. World Health Organization (WHO). Guidelines for Drinking-Water Quality, 4th ed.; Incorporating the first addendum; WHO: Geneva, Switzerland, 2017.

25. Xu, Y.; Usher, B. Groundwater Pollution in Africa; CRC Press: London, UK, 2006. [CrossRef]

26. British Geological Survey (BGS). Assessing Risk to Groundwater from On-Site Sanitation: Scientific Review and Case Studies; BGS: Keyworth, UK, 2002. Available online: http://r4d.dfid.gov.uk/pdf/outputs/r68692.pdf (accessed on 1 February 2020).

27. Graham, J.P.; Polizzotto, M.L. Pit latrines and their impacts on groundwater quality: A systematic review. Environ. Health Perspect. 2013, 121, 521-530. [CrossRef] [PubMed]

28. Al-Atawneh, N.; Mahmoud, N.; van der Steen, P.; Lens, P.N.L. Characterisation of septage in partially sealed cesspit. J. Water Sanit. Hyg. Dev. 2016, 6, 631-639. [CrossRef]

29. Fawell, J.; Bailey, K.; Chilton, J.; Dahi, E.; Fewtrell, L.; Magara, Y. Fluoride in Drinking-Water; WHO/IWA Publishing: Cornwall, UK, 2006

30. Raj, D.; Shaji, E. Fluoride contamination in groundwater resources of Alleppey, southern India. Geosci. Front. 2017, 8, 117-124. [CrossRef]

31. Abed, A.; Al-Wishahi, S.K. Geology of Palestine: The West Bank and Gaza Strip; Palestinian Hydrology Group: Ramallah, Palestine, 1999.

32. Godet, A.; Föllmi, K.B. Sedimentary Phosphate Deposits. In Encyclopedia of Geology, 2nd ed.; Alderton, D., Elias, S.A., Eds.; Academic Press: Cambridge, MA, USA, 2021; pp. 922-930. ISBN 9780081029091. [CrossRef]

33. Hudak, P.F.; Sanmanee, S. Spatial patterns of nitrate, chloride, sulfate, and fluoride concentrations in the Woodbine Aquifer of north-central Texas. Environ. Monit. Assess. 2003, 82, 311-320. [CrossRef] [PubMed]

34. Tirkey, P.; Bhattacharya, T.; Chakraborty, S.; Baraik, S. Assessment of groundwater quality and associated health risks: A case study of Ranchi city, Jharkhand, India. Groundw. Sustain. Develop. 2017, 5, 85-100. [CrossRef]

35. Alam, M.O.; Shaikh, W.A.; Chakraborty, S.; Avishek, K.; Bhattacharya, T. Groundwater arsenic contamination and potential health risk assessment of gangetic plains of Jharkhand, India. Expo. Health 2016, 8, 125-142. [CrossRef]

36. Zhang, Z.; Chen, A. Simultaneous removal of nitrate and hardness ions from groundwater using electrodeionization. Separ. Purif. Technol. 2016, 164, 107-113. [CrossRef]

37. Khan, R.; Jhariya, D.C. Groundwater Quality Assessment for Drinking Purpose in Raipur City, Chhattisgarh Using Water Quality Index and Geographic Information System. J. Geol. Soc. India 2017, 90, 69-76. [CrossRef]

38. World Health Organization (WHO). Calcium and Magnesium in Drinking Water: Public Health Significance; World Health Organization: Geneva, Switzerland, 2009.

39. Ghanem, M.; Jebreen, H.; Sege, J.; Rubin, Y. Investigation of spring water quality in the Natuv catchment, Palestine: A component for the regional environmental management system. Euro-Mediterr. J. Environ. Integr. 2019, 4, 2. [CrossRef]

40. Lloyd, J.W.; Heathcote, J.A. Natural Inorganic Hydrochemistry in Relation to Groundwater, an Introduction; Clarendon Press: Oxford, UK, 1985.

41. Appello, C.A.J.; Postma, D. Geochemistry, Groundwater and Pollution; Balkema: Rotterdam, The Netherlands, 1990.

42. Tesoriero, A.J.; Voss, F.D. Predicting the probability of elevated nitrate concentrations in the Puget Sound basin: Implications for aquifer susceptibility and vulnerability. Ground Water 1997, 35, 1029-1039. [CrossRef] 